$\begin{array}{ccc}\text { UNIVERSITA } & \text { DEPARTMENT OF } \\ \text { DEGLISTUDI } \\ \text { DI TORINO }\end{array}$

\title{
ENTREPRENEURIAL SPIRITS IN WOMEN AND MEN. THE ROLE OF FINANCIAL LITERACY AND DIGITAL SKILLS
}

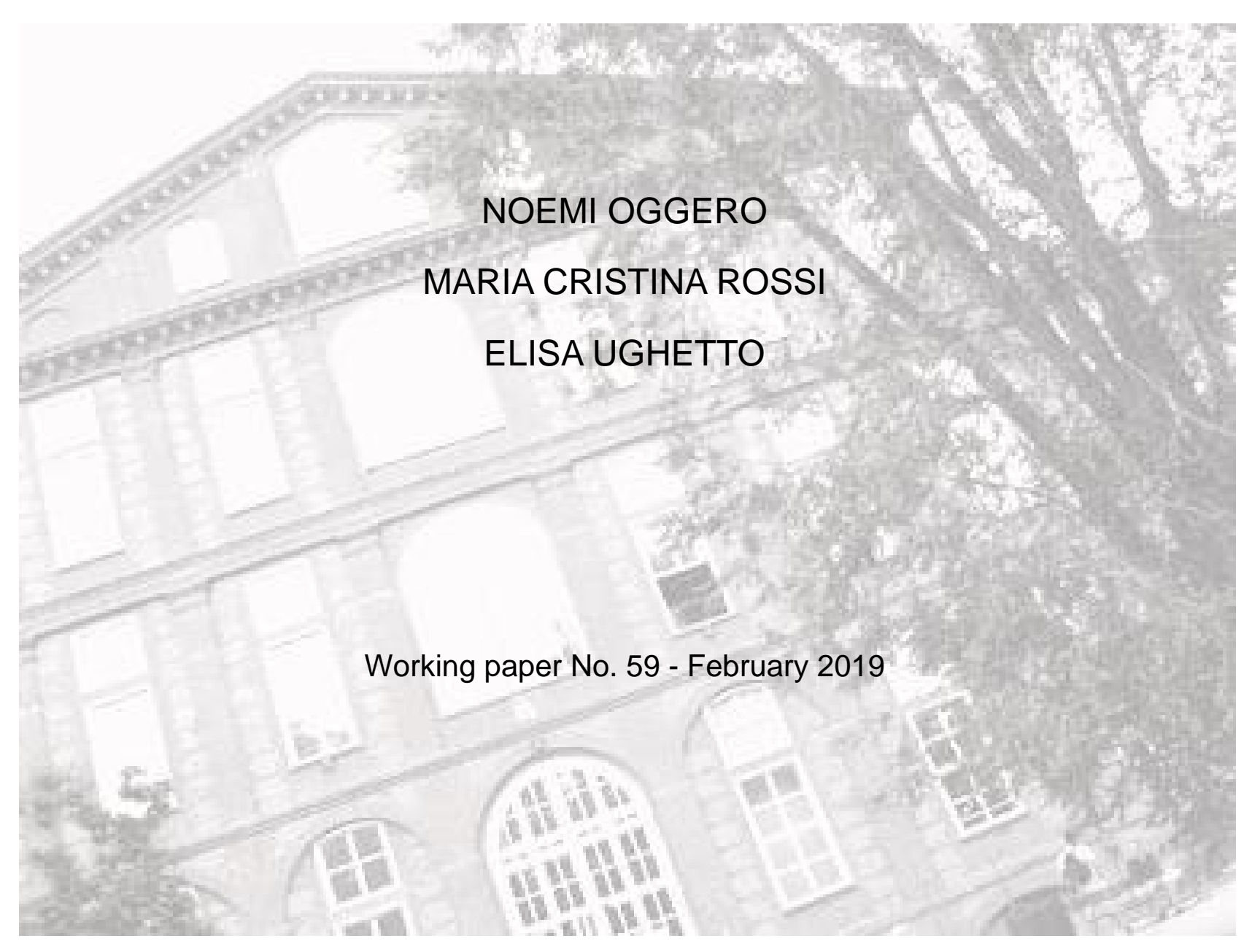




\title{
Entrepreneurial Spirits in Women and Men.
}

\section{The Role of Financial Literacy and Digital Skills}

\author{
Noemi Oggero*, Maria Cristina Rossi**, Elisa Ughetto*** \\ *Università di Torino, Department of Economics, Mathematics and Statistics \\ **Università di Torino, Department of Management, and Collegio Carlo Alberto \\ ***Politecnico di Torino, Department of Management and Production Engineering, and BRICK, \\ Collegio Carlo Alberto
}

\begin{abstract}
We investigate the attitudes to entrepreneurship of Italian households, focusing on the importance of digital skills and financial literacy as potentially relevant factors shaping entrepreneurial entry. We put the gender focus to our analysis to detect whether, and to what extent, women and men differ in their propensity to run a business. We carry out our research by using a sample of the Bank of Italy SHIW dataset for the year 2008 and 2010. Our findings suggest a strong heterogeneity, between men and women, of the importance of digital skills and financial literacy as entrepreneurial drivers. Results show that the impact of financial literacy on the probability of being an entrepreneur is significant, but only for men. Digital skills increase the probability of being entrepreneur with a bigger effect for men than for women.
\end{abstract}

Keywords: entrepreneurship, financial literacy, digital, gender economics

JEL classification: L26, J16, D14 


\section{Introduction}

What drives the choice of being an entrepreneur? It is widely acknowledged that both individual-level (e.g. personality characteristics and attitudes) and contextual factors (e.g. the configuration of the institutional setting, the level of uncertainty of the environment, the nature and degree of complexity of the opportunity itself) shape the decision to become entrepreneurs. Among individual-level factors, financial knowledge and digital skills are important aspects that may drive the process of entering entrepreneurship. However, a lack of systematic empirical evidence has made it difficult to quantify to what extent financial literacy and digital skills can drive the process of becoming entrepreneurs, leaving open a number of important questions. This gap is even more amplified when differences between men and women are considered.

In recent years, the increasing use of advanced digital technologies has involved a transformation of the way to do business, bringing organizational challenges within firms and modifying the ways people work and interact (Autio et al., 2018). New digital paradigms that include a vast array of enabling technologies (e.g. Internet of Things, Augmented and Virtual Reality, Big Data, Artificial Intelligence, Cloud computing) have changed the face of entrepreneurship, as well as the economy as a whole (Rippa and Secundo, 2018; OECD, 2004). An increasing number of businesses now exploit digital platforms, where success requires positioning products and services within digital networks that show complex connections with consumers (Srinivasan and Venkatraman, 2018). The rapid evolution of digital technologies has inevitably shaped, in modern entrepreneurial ecosystems, the production process and GDP formation. It impacts value creation, delivery and capture processes and has led to organizational challenges within and between firms (Autio et al., 2018; Nambisan, 2017; Sussan and Acs, 2017; Verstegen et al., 2018). In this context, a better understanding of how individual expertise and knowledge of digital tools affect entrepreneurial entry and whether, as well as to what extent, this differs between men and women is needed. 
Do digital skills (i.e. the ability to use the computer or other devises, such as smartphones) foster entrepreneurial opportunities, paving the way to the creation of a new businesses? Is there a gender divide in the ability to convert digital skills into entrepreneurial chances? The literature has outlined that digitalization increasingly allows individuals to reach out to peers sharing similar knowledge or tastes (Van Alstyne and Brynjolfsson, 2005). Whilst it has been acknowledged that digital innovation is a powerful channel to enhance and integrate the flows of knowledge among individuals, without restrictions due to geographical boundaries (Autor, 2015), the impact of digital skills on the formation of an entrepreneurial mindset is yet to be fully observed. Moreover, to what extent the effect of digital skills on the formation of entrepreneurial spirits varies between men and women has not been properly investigated yet.

Over the past decades, scholarly attention has advanced understanding of the importance of financial knowledge to make sound financial decisions. Previous literature has documented a strong association between financial literacy and households' financial decision-making, such as wealth accumulation, retirement planning (Bucher-Koenen and Lusardi, 2011; Lusardi and Mitchell, 2007a, 2011a,b; Lusardi et al., 2017; Van Rooij et al., 2012), investment (Disney and Gathergood, 2013; Lusardi and Tufano, 2009; Lusardi and Mitchell, 2007a; Stango and Zinman, 2009) and stock market participation (Jappelli and Padula, 2015; Klapper et al., 2013; Van Rooij et al., 2011). A number of works have documented the presence of gender differences in financial literacy (Almenberg and Dreber, 2015; Lusardi and Mitchell, 2008; Mottola, 2013; Potrich et al., 2015). However, despite the agreement that financial literacy is crucial for financial behavior and well-being, the relationship between entrepreneurship and financial literacy, and how this is affected by gender differences, has been largely under-investigated. This is quite surprising given the importance that financial knowledge plays for an entrepreneur in handling financial risks and opportunities, and in the awareness and understanding of different financing options.

An intertwined aspect concerns whether digital skills act as fly-wheels by strengthening (or rather by weakening) the relation between financial knowledge and entrepreneurial entry. Usage of 
digital technologies may have a major impact on how existing knowledge is absorbed or new knowledge is accessed. The "digital channel" can enhance the impact of financial knowledge: digitalization may facilitate access to financial information and knowledge sharing across individuals, via blogs, websites and other social media sources (Autio et al., 2018). An exploration of the extent to which financial literacy may deter or provide incentives to become entrepreneurs and how this relationship is moderated by the possession of digital skills is certainly a worthy theoretical endeavor in the context of entrepreneurship. An additional question still to be addressed is what is the role played in that regard by gender differences.

In this paper, we provide insight into how financial literacy and digital skills affect the probability of becoming an entrepreneur, looking at gender differences. We contribute to the literature in entrepreneurship in two main ways. First, our study is the first one that elaborates on two nonstandard individual-level factors, namely financial literacy and digital skills, that have never been studied in relation to entrepreneurial entry. Although much research is devoted to the question of what makes an entrepreneur, empirical studies have not gone beyond the examination of how standard individual factors affect entrepreneurship. We have reasons to believe that financial knowledge and digital skills may jointly play a role for the decision to enter entrepreneurship. Second, our paper contributes to the body of knowledge of gender studies. Little is known on whether the gender dimension tailors with a different nuance the impact financial knowledge, as well as the digital skills, have on entrepreneurial decisions. It is even not clear, when gender differences are considered, to what extent digital skills affect the relationship between financial knowledge and the probability to become an entrepreneur. Therefore, in this paper we also explore if any variation is expected when men and women are considered separately.

Putting the gender lenses into the entrepreneurial analysis, it is well established that women have been traditionally more distant from the labour market compared to men, and even more from entrepreneurial tasks. Women are traditionally less prone to entrepreneurial tasks, being less exposed to responsibility tasks since youth. During lifetime, women face higher credit constraints and more 
difficulties in borrowing (Alesina et. al., 2013), which exacerbate their low presence in entrepreneurial activities.

To carry out our analysis, we draw from the Survey of Household Income and Wealth (SHIW) sample, a survey run by the Bank of Italy on a representative sample of Italian households. The dataset is rich because it includes general information about Italian households (such as income and employment status), as well as the level of financial knowledge and a proxy for digital skills. It is useful to stress the key novelty of the dataset we use. Having a sample representative of the Italian population, we can investigate the decision of being an entrepreneur, without restricting our analysis to the choices of entrepreneurs only, like several other studies do by observing the self-selected sample of entrepreneurs only.

The remainder of the paper is organized as follows. Section 2 discusses the background literature and presents our hypotheses. Section 3 introduces the data, describes the methodology adopted in the empirical analysis, and provides some relevant descriptive statistics. Section 4 presents the econometric model and discusses the estimation results. Section 5 concludes the paper.

\section{Hypotheses}

\subsection{Entrepreneurship, financial literacy, and the gender effect}

Financial literacy has been widely regarded as an important component of an individual's background that contributes to make sound informed financial decisions (e.g. financial planning, wealth accumulation, debt, pensions and investment decisions). Financial literacy has been defined as "a combination of awareness, knowledge, skill, attitude, and behavior required to make financial decisions and ultimately achieve individual financial well-being” (OECD, 2013). Financial literacy encompasses a number of concepts (e.g. financial awareness and knowledge, financial skills, and financial capability), that have been operationalized by Lusardi and Mitchell (2007a, 2008) into a predefined set of metrics, initially designed for the US Health and Retirement Study. This financial literacy module has been incorporated into several surveys in the United States (Lusardi et al., 2010; Lusardi and Mitchell, 2011a) 
and abroad (OECD, 2005) and has proved effective in assessing the knowledge of basic financial concepts useful to make responsible financial decisions.

To test basic financial knowledge, a set of questions concerning interest rate, inflation, and risk diversification have been proposed in the literature and consensus on those questions have been reached by experts (Lusardi and Mitchell, 2011c). Attempts have been made to augment basic financial literacy metrics with more sophisticated concepts, such as asset pricing, financial management, and mortgages (Lusardi, 2011).

Research has found that financial illiteracy is widespread and that a large majority of respondents lack the basic knowledge of simple financial concepts (Lusardi and Mitchell, 2014). The same scenario is found when more sophisticated measures of financial literacy are employed (Hilgert et al., 2003; Lusardi et al., 2014). Existing studies have shown that lack of financial literacy is associated with poor borrowing decisions (Disney and Gathergood, 2013; Lusardi and Tufano, 2009; Stango and Zinman, 2009) and investment choices (Bianchi, 2018; Lusardi and Mitchell, 2007a), implying a high reliance on family and friends as the main source of financial advice (Van Rooij et al., 2011). Financial illiterate individuals are less likely to accumulate wealth, plan for retirement (Lusardi and Mitchell, 2007a,b, 2011a,b; Lusardi et al., 2017, 2018; Van Rooij et al., 2012) and to invest in stock (Jappelli and Padula, 2015; Klapper et al., 2013; Van Rooij et al., 2011).

Though there is now a significant empirical body of work on the impact of financial literacy on different types of financial planning decisions, far less attention has been devoted to the links between financial literacy and entrepreneurship. To our knowledge, empirical evidence on this side is scant. A recent paper by Ćumurović and Hyll (2018) investigates the linkage between financial literacy and selfemployment, finding a positive correlation. Bruhn and Zia (2011) and Engström and McKelvie (2017) find that financial literacy led to improved business performance of micro and small firms, in BosniaHerzegovina and Ecuador respectively. 
It is then clear that the question of how financial literacy impacts upon becoming an entrepreneur is still under-examined. Becoming an entrepreneur involves taking sound financial planning and investment decisions, which imply a basic knowledge of financial concepts. Financial management skills and knowledge represent critical competences that entrepreneurs must have in new venture creation and in subsequent venture management. The awareness of basic financial concepts (such as the working of interest compounding, the effects of inflation, the time value of money and diversification potential) constitutes a basis upon which individuals assess the benefits and costs of an entrepreneurial opportunity.

The lack of financial knowledge of entrepreneurs is often portrayed to undermine entrepreneurial activity and to be responsible for high business mortality rates (Bosma and Harding, 2006; Drexler et al., 2014). In fact, if an individual shows low levels of financial literacy, there are reasons to assume that he/she will likely be underprepared to make complex decisions concerning the financial management of a new venture, this in turn affecting the probability of a venture success.

This discussion leads to advance the following hypothesis:

H1. The higher is an individual's financial literacy, the higher is the likelihood to be an entrepreneur.

Differences in financial literacy are also linked to gender issues. Overall, women display a much lower basic financial knowledge compared to men, this being sharper when considering advanced financial literacy (Almenberg and Dreber, 2015; Lusardi and Mitchell, 2008; Mottola, 2013; Potrich et al., 2015). The gender gap is widespread across countries (Bucher-Koenen et al., 2017), being this pattern highest in more developed countries (Cupák et al., 2018). A striking feature is that women are not only less likely to answer financial literacy questions correctly, but also to indicate that they do not know the answer, a result that is consistent across countries (Lusardi and Mitchell, 2011c). Moreover, gender differences are persistent across age, so that women are less financially knowledgeable than men, independently of the considered age (Lusardi et al., 2010; Lusardi and Tufano, 2009). 
Observed gender differences in financial literacy have been largely attributed to sociodemographic, cultural factors, and economic behaviors. In particular, the acquisition of financial knowledge for women within the household clearly depends on the extent to which household tasks are divided and decision-making is allocated (e.g. day-to-day management of household finances; Hsu, 2011). It is also related to what extent socio-cultural dynamics drive the trade-off between benefits and costs of accumulating financial knowledge (e.g. interest in finance matters, passive approach to money). Other approaches have emphasized gender differences in the way financial literacy is acquired (Brown and Graf, 2013; Fonseca et al., 2012) or self-confidence is built (Bucher-Koenen et al., 2017). Given this evidence, we set the following declination of the first hypothesis:

H1a. The positive association between financial literacy and likelihood to be entrepreneurs is affected by gender differences, such that individuals with financial literacy are more likely to be entrepreneurs if they are men.

\subsection{Entrepreneurship, digital skills, and the gender effect}

Today's jobs require more complex skills than in the past, and changes in skill requirements have been most pronounced in rapidly computerizing occupations (Spitz-Oener, 2006). Indeed, computer capital substitutes for workers in performing tasks that can be accomplished by following explicit rules, but it only complements workers in performing problem-solving and complex tasks (Autor et al., 2003). More specifically, Autor (2015) argues that the interplay between machine and human comparative advantage allows computers to substitute for workers in performing routine and codifiable tasks, while amplifying the comparative advantage of workers in supplying problem-solving skills, adaptability, and creativity. Atalay et al. (2018) also estimate that information and communication technologies (ICTs) have shifted workers away from routine tasks towards more knowledge-intensive jobs. On the other hand, Consoli et al. (2016) find that higher non-routine skill intensity has had only a modest effect on productivity and wages, except in high-skill occupations. Similarly, Borghans and ter Weel (2006), using information from the 1997 Skills Survey of the Employed British Workforce, show 
that computer skills do not yield significant labour-market returns for most types of use, suggesting returns to computer skills at the highest level of sophistication of use only.

The world of entrepreneurship has changed a lot during the past few years, fueled by access to ICTs, new open innovation tools, and the increasing importance of digital platforms for value creation and delivery. ICTs have altered the nature and pursuit of entrepreneurship, by creating many opportunities for entrepreneurs and their firms, from serving as an input for innovation for established firms to participating as complementors on existing platforms (Nambisan et al., 2018).

What the literature agrees on is that the Internet can extend market reach and operational efficiency of new ventures and small and medium enterprises (SMEs), and enhance their contributions to the economy. As showed by Bi et al. (2017), IT resources and strategic IT alignment contribute significantly to SMEs' performance through the development of e-business capability and business process competence. Dholakia and Kshetri (2004) suggest that specific factors contribute to the SMEs' involvement with the Internet, such as prior technology use and the customer service perceived competitive pressure. However, small firms generally lag behind medium and large companies in adopting and implementing computerization.

In this context, new competences emerge to accommodate the digital transition of entrepreneurship. Digitalization implies skill requirements that can be different within and across firms and industries and that are constantly changing, replacing obsolete or redundant existing ones (Autor, 2015). Lee et al. (2009) show that individual digital knowledge and both traditional and electronic communication methods significantly contribute to the internal process performance of small firms. This implies that adopting computerization is fundamental for small firms to achieve improvements in business performance. Moreover, banks tend to grant increasing volumes of credit to enterprises that use ICT more extensively (Dalla Pellegrina et al., 2017).

We thus advance and want to test the following hypothesis:

H2. The higher are an individual's digital skills, the higher is the likelihood to be an entrepreneur. 
While research shows that ICT is a unique opportunity, many women still face a digital divide. Hafkin and Huyer (2007) argue that to fully participate in knowledge-based activities, women need access not only to new technologies, but also to education and entrepreneurship opportunities. The gender divide tends to narrow at higher levels of education, but another factor that affects ICT use by gender is age: the proportion of female Internet users decline steeply with age (Huyer et al., 2005).

The issue of the gender divide is much broader than ICT access and penetration: even in countries where access is no longer much of an issue and penetration is high, inequalities in actual use can hinder women's economic development opportunities (Hafkin and Huyer, 2007). Brush (1992) also notices that women view their businesses as an interconnected system of relationships, suggesting that female business owners demonstrate a preference for socially based knowledge with cooperative, less individualistic and competitive means of learning.

Overall, there has been a lack of attention to increasing female entrepreneurs' opportunities to develop their full potential in the knowledge economy: most training programs do not deliver sufficient, comprehensive digital and strategic skills required for full participation to a knowledge society (Braun, 2010). Braun (2010) also highlights that this issue needs to be addressed for both men and women, but with entrepreneurial opportunities for women gradually increasing, women's entrepreneurial capacity should be supported by a comprehensive skill set. Given the evidence reported here, we expect that:

H2a. The positive association between digital skills and likelihood to be entrepreneurs is affected by gender differences, such that individuals with digital skills are more likely to become entrepreneurs if they are men.

\subsection{Entrepreneurship, digital skills, and financial literacy}

A recent study by Grundke et al. (2018) finds that digital intensive industries especially reward workers having advanced numeracy skills. In fact, specific sets of skills are particularly important for workers in such industries: those having a high level of numeracy skills receive an additional wage 
premium, if they also show other traits like high levels of self-organization or managing and communication skills. Therefore investigating the separate contributions of financial literacy and digital skills to entrepreneurship is of particular interest, as is understanding how they interact and impact the entrepreneurial outcome.

Looking at the interplay between digital skills and financial literacy in personal finances, Yakobowski et al. (2018) find that fin-tech users benefit from being financially literate, as those with higher levels of financial literacy are less likely to show bad personal finance outcomes. Thus fin-tech (i.e., using smartphones for financial purposes) and financial literacy are viewed as complements. Just as the use of fin-tech in combination with financial literacy has the potential to improve personal finance outcomes (Yakobowski et al., 2018), we expect digital skills to enhance the impact of financial literacy on being an entrepreneur, that is:

H3. Digital skills have a moderating effect on the impact that financial literacy has on the likelihood of being an entrepreneur.

\section{Data and Methodology}

The data used in our empirical analysis are drawn from the Survey of Household Income and Wealth (SHIW), which is conducted every two years by the Bank of Italy for a representative sample of the Italian population. The SHIW dataset contains several information about Italian households, including household composition and characteristics, income and employment status, and a proxy for digital skills. In the 2008 and 2010 waves, in addition to the standard questionnaire, the whole sample was given an extra module designed to gauge households' basic level of financial knowledge. Some financial literacy questions started being included in the SHIW in 2006, but it was just in 2008 and 2010 that both risk diversification and inflation concepts were tested in the survey, through questions very similar to the ones designed for the US Health and Retirement Study by Lusardi and Mitchell (2011b). Since in this paper we want to investigate the impact of basic financial knowledge on being an 
entrepreneur, we use pooled data from both 2008 and 2010 waves. Financial literacy questions were dropped from the survey in the successive wave.

The 2008 survey covers 7,977 households composed of 19,907 individuals, while the 2010 wave covers 7,951 households for a total of 19,836 individuals. By restricting the sample to household heads and their spouses/partners aged 18 or more, we are left with a sample of 26,032 individuals from 15,921 households.

The SHIW dataset allows us to gather information on many socio-demographic characteristics that are relevant for our research question, like gender, age, region, educational attainment, marital status, having children, income, and employment status (detailed variable explanations and descriptive statistics are displayed in Tables $1 \mathrm{a}$ and $1 \mathrm{~b})$.

\section{[Insert Tables $1 \mathrm{a}$ and $1 \mathrm{~b}$ here]}

Since the survey does not provide information on the actual intention to become entrepreneur or how long individuals have been entrepreneurs, we exploit the employment status information to investigate factors affecting the probability to become an entrepreneur. Our first definition of entrepreneur (i.e. narrow definition) includes individuals who are either individual entrepreneurs, or owners or members of family businesses. According to this definition, entrepreneurs are $2 \%$ of our sample. We also provide a second and broader definition of entrepreneur (i.e. broad definition) that includes professionals, self-employed craftsmen, business partners, and covers around $8 \%$ of the sample. Self-employment is treated by numerous scholars as entrepreneurship (see for instance Astebro and Thompson, 2011; Chihmao et al., 2017; Folta et al., 2010; Nanda and Sorensen, 2010). In order to define our first variable of interest, i.e. basic financial knowledge, we follow Lusardi and Mitchell (2011b) by using as a measure of financial literacy an indicator equal to 1 if the respondent answered correctly the questions capturing the three basic economic concepts of interest rate, inflation, and risk diversification. In the SHIW, the interest rate concept just appears as part of the inflation question; the precise wording of the two questions is as follows: 
Interest rate and inflation concepts: Imagine leaving $€ 1,000$ in a current account that pays $1 \%$ interest and has no charges. Imagine that inflation is running at $2 \%$. Do you think that if you withdraw the money in a year's time you will be able to buy the same amount of goods as if you spent the $€ 1,000$ today?

Possible answers: Yes; No, I will be able to buy less; No, I will be able to buy more; Don't know.

Risk diversification concept. Which of the following investment strategies do you think entails the greatest risk of losing your capital?

Possible answers: Investing in the shares of a single company; Investing in the shares of more than one company; Don't know.

About $43 \%$ of individuals in the sample can be defined financially literate, i.e. they answered correctly to both questions.

For what concerns our second variable of interest, we proxy basic digital skills using a question in the survey that asks the household head, who is the person primarily responsible for the household budget, whether a member of the household used a computer (or telephone) to be in contact/do business with banks or financial intermediaries in the year of the interview (i.e. 2008 or 2010). In doing so, we follow Falck et al. (2016) in the underlying idea that digital skills are developed through learningby-doing, which is facilitated when having access to the Internet (i.e., Internet access is important in the formation of digital skills). Similarly, Kyndt et al. (2009) define digital learning as an unplanned and implicit process using several types of technological devices like smartphones, tablets, and computers.

Since both age and gender dimensions are used in the analysis, Table 2 reports descriptive statistics separately for men and women, and individuals younger and older than 50 , which is about the average age of entrepreneurs in our sample. Statistics show that financial knowledge is higher among men with respect to women: almost $46 \%$ of men are financially literate compared to about $42 \%$ of women. The percentage of individuals with digital skills and entrepreneurs is slightly higher among men, too. 
Table 2 also shows that individuals who are 50 years old or younger are more educated, more financially literate, more digitally skilled, and include a larger fraction of entrepreneurs. Research has shown that financial literacy (both basic and advanced) is highest among middle-aged individuals, while it is lowest among the youngest and eldest people (Van Rooij et al., 2011). Financial literacy is found to decline with age both in the US and other countries (Lusardi and Mitchell, 2011a,c), even though the perceived confidence in one's own financial decision-making abilities seems to increase with age (Lusardi et al., 2014). This gap persists also when more sophisticated literacy questions are administered.

Graphs 1 and 2 show the probability of being entrepreneur by gender and financial literacy levels.

$$
\text { [Insert Graphs } 1 \text { and } 2 \text { here] }
$$

Interestingly, the probability of being entrepreneur is on average higher for financially literate men than, in this order, not financially literate men, financially literate women, and not financially literate women. And this holds true for both the definitions of entrepreneurs we adopted.

Similarly, the likelihood of being entrepreneur is on average higher for digitally skilled men than, in this order, not digitally skilled men, digitally skilled women, and not digitally skilled women (Graphs 3 and 4). This peaking order is particularly clear when looking at the second definition of entrepreneurs.

\section{[Insert Graphs 3 and 4 here]}

The four graphs seem to indicate that gender plays a role when dealing with factors associated with entrepreneurship such as financial knowledge and digital skills.

\section{Estimation Results}


A multivariate analysis of the effect of financial literacy and digital skills on being an entrepreneur is conducted estimating a linear probability model of the following specification:

$$
\text { Entrepreneur }{ }_{i t}=\beta_{0}+\beta_{1} \text { Financial Literacy }_{i t}+\beta_{2} \text { Digital Skills }_{i t}+\beta_{3} \text { Financial Literacy }_{i t}^{*} \text { Digital Skills }_{i t}+\beta_{4} X_{i t}+\varepsilon_{i t}
$$

where Entrepreneur, Financial Literacy, and Digital Skills are the variables of interest, and $X$ is a vector of covariates including gender, region, a second-order polynomial in age, educational attainment, marital status, the logarithm of income, having children living in the same dwelling, and the year of the interview. In the full specification of our estimates, we also add the interaction variable Financial Literacy*Digital Skills to test whether having digital skills increases the effect of financial literacy on being an entrepreneur. Table 3 summarizes the results for both definitions of entrepreneur: the first four columns refer to the restrictive definition - i.e. individual entrepreneurs, or owners or members of family businesses - while columns 5 to 8 show the estimation results for a broader definition of entrepreneurs, which includes professionals, self-employed craftsmen, and business partners as well.

\section{[Insert Table 3 bere]}

Columns 1 and 5 of Table 3, where only socio-demographics are included, show that women are less likely to be entrepreneur even after controlling for many characteristics like geographical area, age, education, marital status, having children, and income. There is also a negative correlation between being married and having a business. On the other hand, having children and higher income is positively correlated with being an entrepreneur. In the second and sixth columns of Table 3 , we add a measure for financial knowledge, and coefficients on the other covariates remain almost the same as before, meaning that financial literacy is really capturing something different from the other controls. In particular, financial knowledge seems to have a statistically significant effect only when looking at the more inclusive definition of entrepreneurs (column 6). This result is confirmed when we add a proxy for digital skills. Digital skills have a positive effect on being an entrepreneur when both the narrow and broad definitions are considered, with significance at 10\% and 1\% levels respectively (columns 3 and 7). The last specifications (columns 4 and 8) show that financial knowledge and digital skills have both 
positive but independent effects on the probability of an individual to become entrepreneur. Indeed, the interaction between the two variables is not statistically significant.

While the results discussed above seem to be in line with our hypotheses, we are interested in factors driving the event of becoming an entrepreneur, thus we want to focus on individuals closer to the point in time when this event happened. In fact, if a person has been an entrepreneur for many years, a lot of factors may have changed over time since the entrepreneurial decision was made. Unfortunately, we do not have information about how long individuals have been entrepreneurs, thus we use a criterion based on age, and we focus on younger individuals. In particular, we split the sample at age 50, which is about the average age of entrepreneurs in our sample (similar results are obtained if the threshold is considered to be at age 45). The results for the two sub-samples are shown in Table 4.

\section{[Insert Table 4 here]}

Focusing on our sample of interest, i.e. the younger one, we notice that financial literacy has a positive impact on being an entrepreneur, for both the definitions used (first and third columns of Table 4). Moreover, we notice that financial literacy is positively associated with the likelihood of being an entrepreneur even after controlling for the educational level. This means that financial knowledge has an effect above and beyond the impact of education. Thus, this result confirms our first hypothesis H1. This is also consistent with Ćumurović and Hyll (2018) who find that financial literacy positively affects the probability of being self-employed.

In line with $\mathrm{H} 2$, individuals with digital skills are associated with a higher likelihood to be entrepreneurs for the sample of younger individuals, but just when considering the broader definition (third column of Table 4). The interaction between financial knowledge and digital skills is not significant also when considering the younger subsample. Financial and digital knowledge have positive and independent effects on being an entrepreneur, hence there is not a mediation effect of the drivers of entrepreneurship and our $\mathrm{H} 3$ is not verified. In addition, regression results from Table 4 show that 
women are still less likely to be entrepreneurs even after accounting for financial knowledge, digital skills, and many socio-demographic characteristics.

Up to now, we have assumed that financial literacy and digital skills have the same effect on the probability of being an entrepreneur for both men and women. However, since we are interested in the gender perspective, in Table 5 we allow all characteristics to have different effects on men and women's probability of being an entrepreneur.

\section{[Insert Table 5 bere]}

Interestingly, financial knowledge has a positive effect only on men's probability of being an entrepreneur, and it is never statistically significant for women, as shown in the first and third columns of Table 5. These results confirm the hypothesis H1a. Similarly, digital skills increase men's probability of being entrepreneur when considering the broader definition of entrepreneurs, and they have an impact only at $10 \%$ significance level (which is also one third in magnitude) on female entrepreneurship. Hence, we find only partial evidence supporting H2a. Once again, we do not find evidence of the mediator effect of digital skills in the impact of financial literacy on entrepreneurship, when both men and women are considered. Indeed, the interaction variable is never significant.

\section{Conclusions}

Over the past decades, scholarly attention has advanced understanding of the factors affecting the decision to become an entrepreneur. Nevertheless, entrepreneurship research has ignored the role that some individual level factors play in entrepreneurship, such as financial literacy and digital skills. This work has investigated the drivers for entrepreneurship by finding a substantial heterogeneity in the impact that financial knowledge and digital skills have on becoming an entrepreneur. This heterogeneity mainly resides in the gender dimension. 
Our results show that, after controlling for many characteristics like geographical area, age, education, marital status, having children, and income, financial knowledge positively and significantly affects the probability of being an entrepreneur. However, this channel is at work for men only. At the same time, digital skills are helpful to start an entrepreneurial career, and a bigger effect is found for men than for women. Hence, women's decisions to become entrepreneurs seem not to be shaped by financial knowledge and only partially by digital skills, and external factors (such as social norms including family social norms) probably act as the main driver.

A better understanding of the role played by financial literacy and digital skills in entrepreneurship and of the different nuances affecting the gender dimension, has the potential to move the discussion forward and to improve the awareness of entry decisions in new ventures for potential entrepreneurs. Future research should explore in more detail how digital competences and financial skills will shape the rate and direction of entrepreneurship activity and whether a gender gap will continue to persist. A number of related questions might be raised in future studies. Is the combination of digital skills and financial knowledge more conducive to better firm performances? How does the role of digital skills and financial literacy vary across different geographic regions and sectors or across contexts in which the gender gap is more deep rooted? What will be their long lasting effects on the creation and outcomes of entrepreneurial ecosystems?

Our findings offer important implications for policy makers. Policy makers often discuss how to create support measures which act as a stimulus towards entrepreneurship. While many governments seem to be concerned about financial literacy levels and about digitalization of the economy, it seems that the role played by financial knowledge and digital skills in entrepreneurship is not well recognized yet. This is surprising given that such skills contribute to decisions about taking an entrepreneurial career and are thus ultimately affecting entrepreneurial rates and paths. In this context, effective approaches to enhance the financial and digital knowledge of individuals should be a top priority for policymakers. In particular, women should be the focal lens of policy interventions of this kind. As both financial literacy and digital knowledge are acquirable, our findings suggest that it might be worth 
creating tailored training and educational programs to alleviate financial and digital illiteracy, especially among women, which are the most vulnerable group. One of the possible actions to be taken pertains to the reinforcement of women's interest in financial and digital matters, beginning from the early levels of education. Courses that combine the teaching of basic financial and computer science concepts with a practice-oriented training at all levels of society could help to reduce, in the long run, gender inequalities. In addition, the inclusion of financial management and computer science disciplines in all undergraduate courses, regardless of the specific field of study, could have the potential to better align education to the needs of entrepreneurship.

\section{Tables and graphs}

\section{Graph 1}

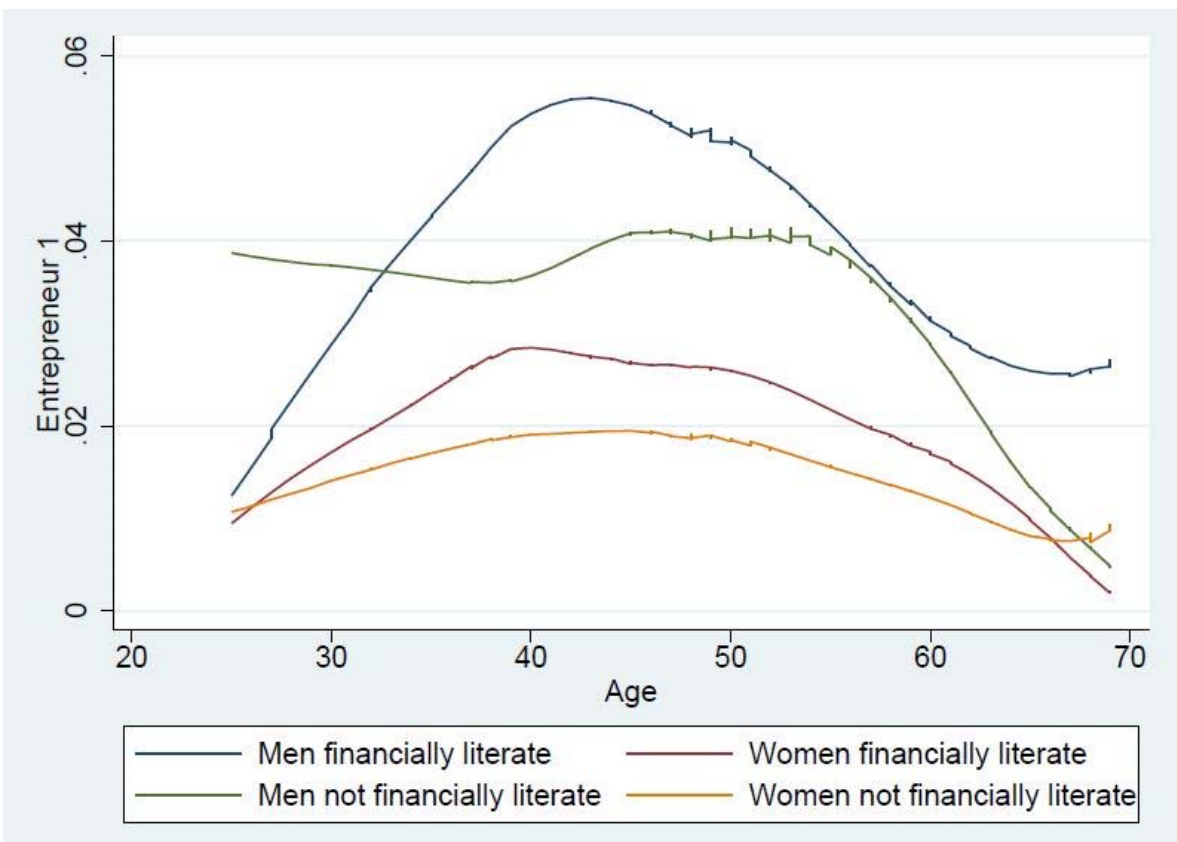

Note: The sample includes individuals aged 25-69 in the 2008 and 2010 SHIW (i.e. the first/last age for which the number of entrepreneurs is greater than 2). "Entrepreneurs 1" include individual entrepreneurs, and owners or members of a family business (i.e. narrow definition).

\section{Graph 2}




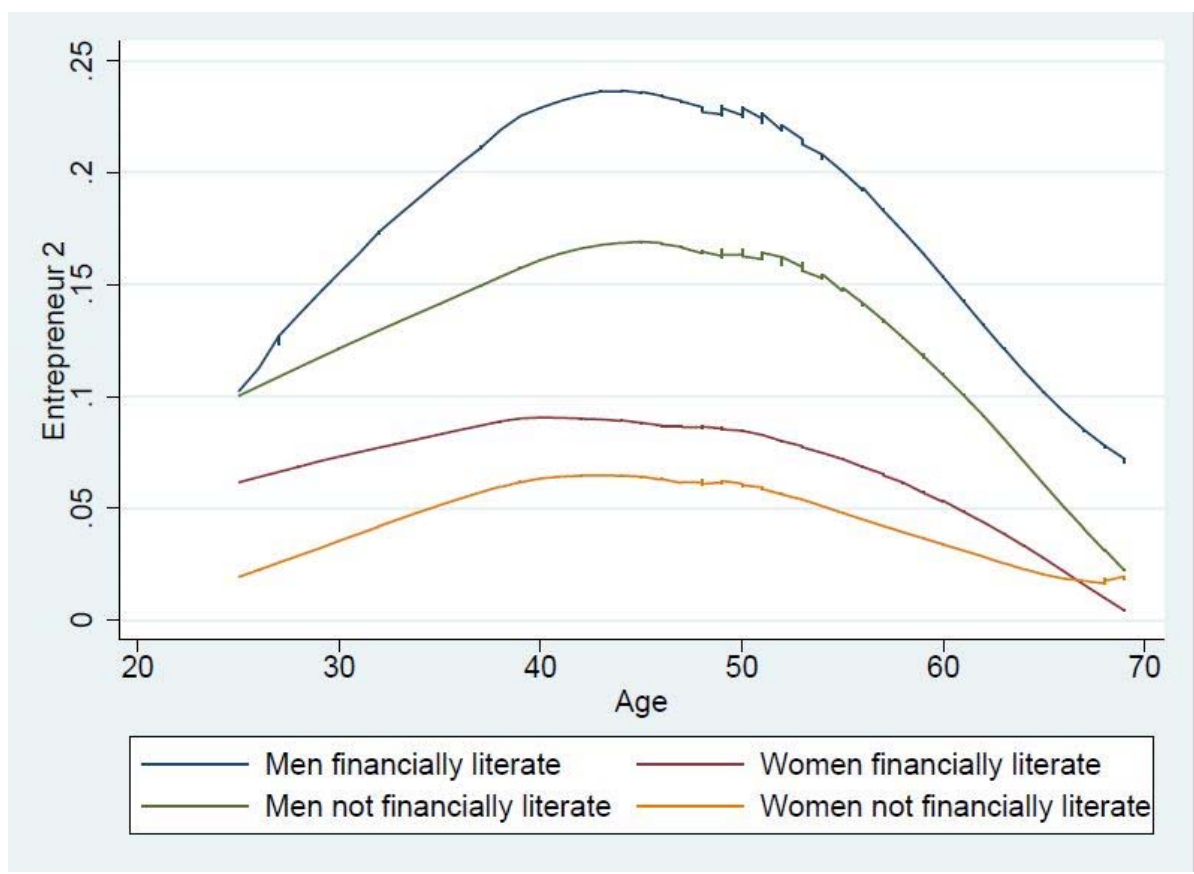

Note: The sample includes individuals aged 25-69 in the 2008 and 2010 SHIW. "Entrepreneurs 2" include individual entrepreneurs, owners or members of a family business, professionals, self-employed craftsmen, and business partners (i.e. broad definition).

\section{Graph 3}

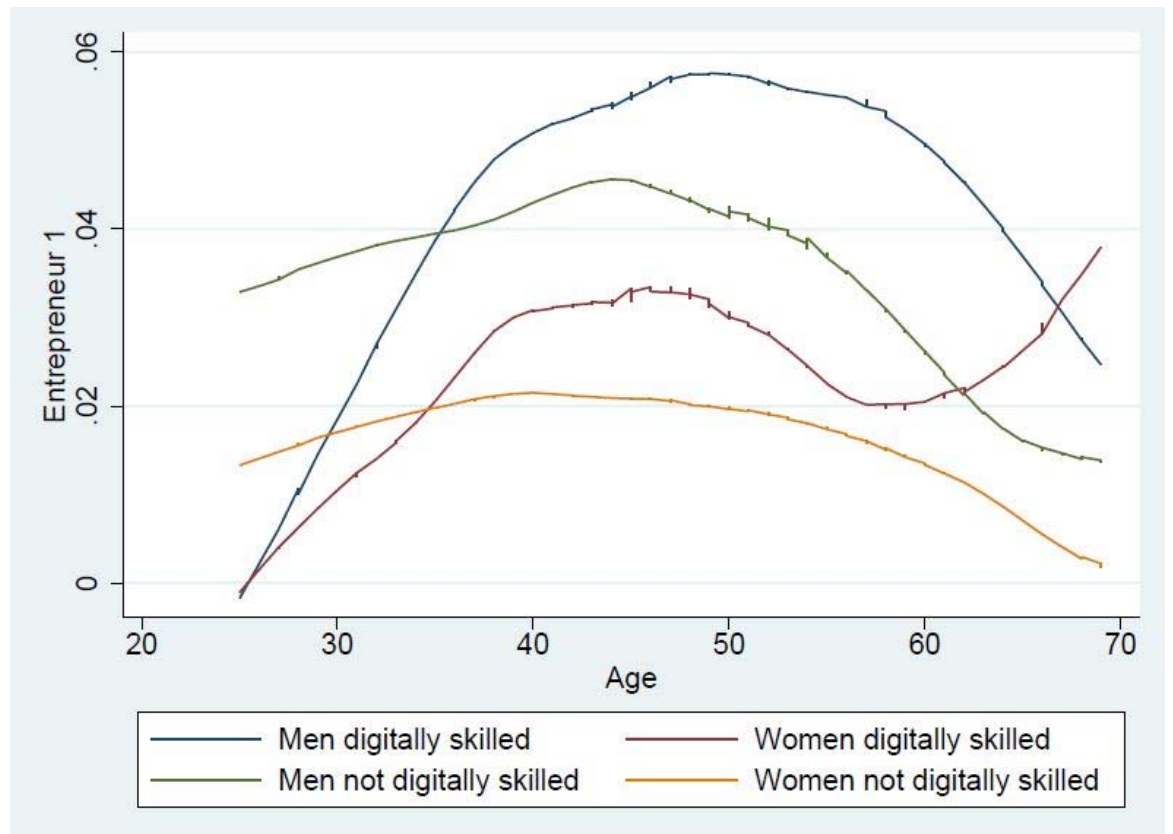

Note: The sample includes individuals aged 25-69 in the 2008 and 2010 SHIW (i.e. the first/last age for which the number of entrepreneurs is greater than 2). "Entrepreneurs 1" include individual entrepreneurs, and owners or members of a family business (i.e. narrow definition).

\section{Graph 4}




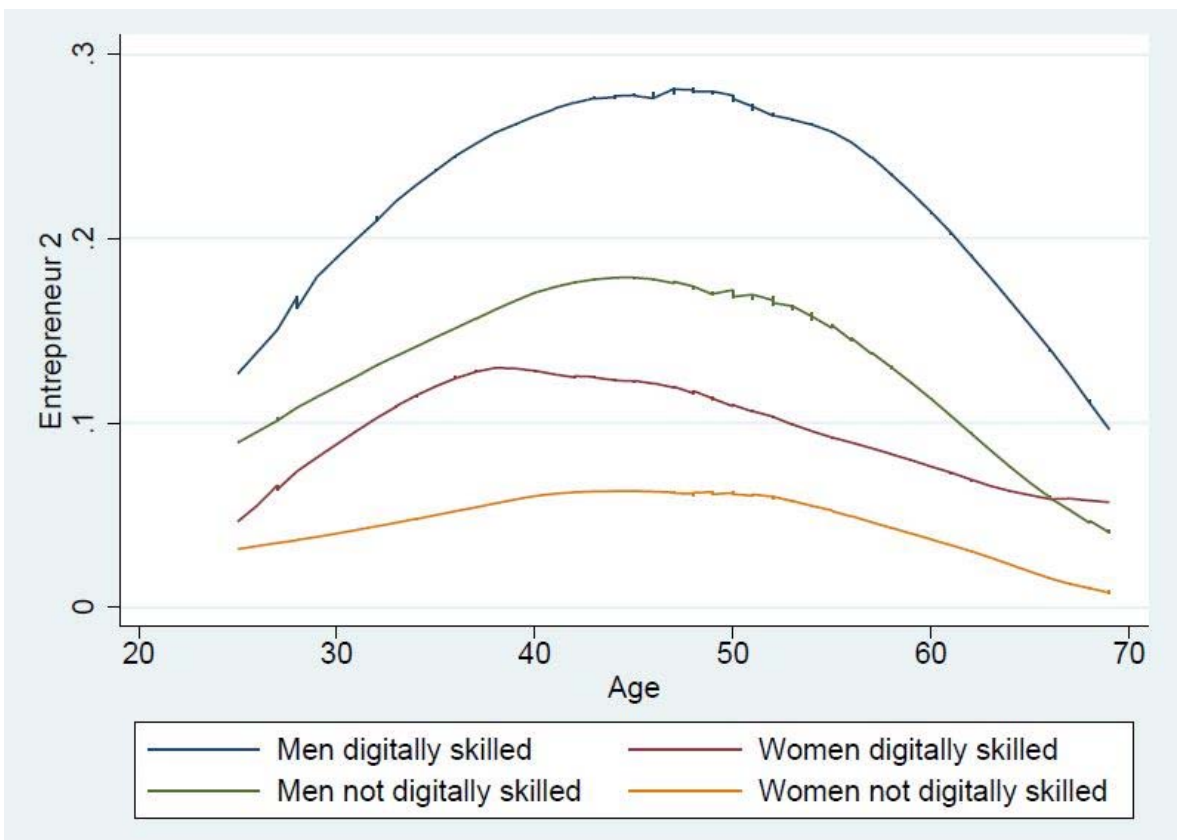

Note: The sample includes individuals aged 25-69 in the 2008 and 2010 SHIW. "Entrepreneurs 2" include individual entrepreneurs, owners or members of a family business, professionals, self-employed craftsmen, and business partners (i.e. broad definition). 
Table 1a: Variable Description

\begin{tabular}{|c|c|}
\hline Variable & Description \\
\hline Female & Dummy: 1 if female, 0 if male \\
\hline Center & Dummy: 1 if living in central Italian regions, 0 otherwise \\
\hline South & Dummy: 1 if living in southern Italian regions or islands, 0 otherwise \\
\hline Age & Age \\
\hline Married & Dummy: 1 if married, 0 otherwise \\
\hline Children & Dummy: 1 if at least one child is a member of the household, 0 otherwise \\
\hline High school & $\begin{array}{l}\text { Dummy: } 1 \text { if the respondent has vocational secondary school diploma (3 } \\
\text { years of study after middle school) or upper secondary school diploma, } 0 \\
\text { otherwise }\end{array}$ \\
\hline Degree & $\begin{array}{l}\text { Dummy: } 1 \text { if the respondent has } 3 \text {-year university degree/higher } \\
\text { education diploma, or } 5 \text {-year university degree, or postgraduate } \\
\text { qualification, } 0 \text { otherwise }\end{array}$ \\
\hline Log Income & Logarithm of net disposable income \\
\hline Financial Literacy & $\begin{array}{l}\text { Dummy: } 1 \text { if the respondent answered correctly to both inflation } \\
\text { (including interest rate concept) and risk diversification questions, } 0 \\
\text { otherwise }\end{array}$ \\
\hline Digital Skills & $\begin{array}{l}\text { Dummy: } 1 \text { if a member of the household used a computer (or telephone) } \\
\text { to be in contact with banks or financial intermediaries in the year of the } \\
\text { interview, } 0 \text { otherwise }\end{array}$ \\
\hline $\begin{array}{l}\text { Entrepreneur } 1 \text { (narrow } \\
\text { definition) }\end{array}$ & $\begin{array}{l}\text { Dummy: } 1 \text { if the respondent is either an individual entrepreneur, or owner } \\
\text { or member of a family business }\end{array}$ \\
\hline $\begin{array}{l}\text { Entrepreneur } 2 \text { (broad } \\
\text { definition) }\end{array}$ & $\begin{array}{l}\text { Dummy: } 1 \text { if the respondent is an individual entrepreneur, owner or } \\
\text { member of a family business, a professional, a self-employed craftsman, } \\
\text { or a business partner }\end{array}$ \\
\hline
\end{tabular}


Table 1b: Descriptive Statistics $(n=26,032)$

\begin{tabular}{|c|c|c|c|c|c|}
\hline Variable & Mean & Std. dev. & Min & Max & Median \\
\hline Female & 0.54 & 0.14 & 0 & 1 & 1 \\
\hline Center & 0.21 & 0.41 & 0 & 1 & 0 \\
\hline South & 0.34 & 0.47 & 0 & 1 & 0 \\
\hline Age & 56.80 & 15.23 & 18 & 103 & 56 \\
\hline High school & 0.32 & 0.46 & 0 & 1 & 0 \\
\hline Degree & 0.10 & 0.30 & 0 & 1 & 0 \\
\hline Married & 0.76 & 0.42 & 0 & 1 & 1 \\
\hline Children & 0.53 & 0.50 & 0 & 1 & 1 \\
\hline Log Income & 10.24 & 0.79 & 0 & 13.35 & 10.28 \\
\hline Financial Literacy & 0.43 & 0.49 & 0 & 1 & 0 \\
\hline Digital Skills & 0.16 & 0.36 & 0 & 1 & 0 \\
\hline Entrepreneur 1 & 0.02 & 0.14 & 0 & 1 & 0 \\
\hline Entrepreneur 2 & 0.08 & 0.28 & 0 & 1 & 0 \\
\hline
\end{tabular}


Table 2: Descriptive Statistics by Gender and Age Groups

\begin{tabular}{|l|c|c|c|c|c|c|}
\hline & \multicolumn{3}{|c|}{ Male (n=11,969) } & \multicolumn{3}{c|}{ Female (n=14,063) } \\
\hline Variable & Mean & Std. dev. & Median & Mean & Std. dev. & Median \\
\hline Center & 0.21 & 0.41 & 0 & 0.21 & 0.41 & 0 \\
\hline South & 0.34 & 0.47 & 0 & 0.34 & 0.47 & 0 \\
\hline Age & 57.14 & 14.76 & 57 & 56.50 & 15.61 & 56 \\
\hline High school & 0.33 & 0.47 & 0 & 0.30 & 0.46 & 0 \\
\hline Degree & 0.10 & 0.31 & 0 & 0.10 & 0.30 & 0 \\
\hline Married & 0.83 & 0.37 & 1 & 0.70 & 0.46 & 1 \\
\hline Children & 0.54 & 0.50 & 1 & 0.52 & 0.50 & 1 \\
\hline Log Income & 10.29 & 0.78 & 10.34 & 10.20 & 0.79 & 10.24 \\
\hline Financial Literacy & 0.46 & 0.50 & 0 & 0.42 & 0.49 & 0 \\
\hline Digital Skills & 0.17 & 0.37 & 0 & 0.15 & 0.35 & 0 \\
\hline Entrepreneur 1 & 0.03 & 0.17 & 0 & 0.01 & 0.12 & 0 \\
\hline Entrepreneur 2 & 0.13 & 0.33 & 0 & 0.05 & 0.21 & 0 \\
\hline
\end{tabular}

\begin{tabular}{|l|c|c|c|c|c|c|}
\hline & \multicolumn{3}{|c|}{ Age $\leq \mathbf{5 0}(\mathrm{n}=9,730)$} & \multicolumn{3}{c|}{ Age $\mathbf{5 0}$ (n=16,302) } \\
\hline Variable & Mean & Std. dev. & Median & Mean & Std. dev. & Median \\
\hline Female & 0.56 & 0.50 & 1 & 0.53 & 0.50 & 1 \\
\hline Center & 0.19 & 0.39 & 0 & 0.22 & 0.41 & 0 \\
\hline South & 0.36 & 0.48 & 0 & 0.33 & 0.47 & 0 \\
\hline Age & 40.85 & 6.78 & 42 & 66.31 & 10.03 & 65 \\
\hline High school & 0.45 & 0.50 & 0 & 0.24 & 0.43 & 0 \\
\hline Degree & 0.13 & 0.34 & 0 & 0.08 & 0.27 & 0 \\
\hline Married & 0.80 & 0.40 & 1 & 0.74 & 0.44 & 1 \\
\hline Children & 0.75 & 0.43 & 1 & 0.40 & 0.49 & 0 \\
\hline Log Income & 10.20 & 0.93 & 10.30 & 10.27 & 0.69 & 10.28 \\
\hline Financial Literacy & 0.48 & 0.50 & 0 & 0.41 & 0.49 & 0 \\
\hline Digital Skills & 0.23 & 0.42 & 0 & 0.11 & 0.32 & 0 \\
\hline Entrepreneur 1 & 0.03 & 0.18 & 0 & 0.01 & 0.12 & 0 \\
\hline Entrepreneur 2 & 0.13 & 0.33 & 0 & 0.06 & 0.23 & 0 \\
\hline
\end{tabular}


Table 3. Multivariate Regression Model of the Probability of Being Entrepreneur

\begin{tabular}{|c|c|c|c|c|c|c|c|c|}
\hline & \multicolumn{4}{|c|}{ Entrepreneur 1 (narrow definition) } & \multicolumn{4}{|c|}{ Entrepreneur 2 (broad definition) } \\
\hline & $\mathrm{I}$ & II & III & IV & $\mathrm{V}$ & VI & VII & VIII \\
\hline \multirow[t]{2}{*}{ Female } & $-0.015^{* * *}$ & $-0.015^{* * *}$ & $-0.015^{* * *}$ & $-0.015^{* * *}$ & $-0.082 * * *$ & $-0.082^{* * *}$ & $-0.081 * * *$ & $-0.082 * * *$ \\
\hline & $(0.002)$ & $(0.002)$ & $(0.002)$ & $(0.002)$ & $(0.004)$ & $(0.004)$ & $(0.004)$ & $(0.004)$ \\
\hline \multirow[t]{2}{*}{ Center } & 0.001 & 0.001 & 0.001 & 0.001 & 0.007 & 0.006 & 0.006 & 0.006 \\
\hline & $(0.003)$ & $(0.003)$ & $(0.003)$ & $(0.003)$ & $(0.006)$ & $(0.006)$ & $(0.006)$ & $(0.006)$ \\
\hline \multirow[t]{2}{*}{ South } & 0.003 & 0.003 & 0.004 & 0.004 & 0.002 & 0.003 & 0.008 & 0.007 \\
\hline & $(0.003)$ & $(0.003)$ & $(0.003)$ & $(0.003)$ & $(0.005)$ & $(0.005)$ & $(0.005)$ & $(0.005)$ \\
\hline \multirow[t]{2}{*}{ Age } & 0.000 & 0.000 & 0.000 & 0.000 & $0.004 * * *$ & $0.004 * * *$ & $0.004 * * *$ & $0.004 * * *$ \\
\hline & $(0.000)$ & $(0.000)$ & $(0.000)$ & $(0.000)$ & $(0.001)$ & $(0.001)$ & $(0.001)$ & $(0.001)$ \\
\hline \multirow[t]{2}{*}{ Age squared } & $-0.000 * * *$ & $-0.000 * * *$ & $-0.000 * * *$ & $-0.000 * * *$ & $-0.000 * * *$ & $-0.000 * * *$ & $-0.000 * * *$ & $-0.000^{* * * *}$ \\
\hline & $(0.000)$ & $(0.000)$ & $(0.000)$ & $(0.000)$ & $(0.000)$ & $(0.000)$ & $(0.000)$ & $(0.000)$ \\
\hline \multirow[t]{2}{*}{ High school } & -0.002 & -0.002 & -0.003 & -0.003 & 0.008 & 0.006 & 0.001 & 0.002 \\
\hline & $(0.003)$ & $(0.003)$ & $(0.003)$ & $(0.003)$ & $(0.005)$ & $(0.005)$ & $(0.005)$ & $(0.005)$ \\
\hline \multirow[t]{2}{*}{ Degree } & $-0.017 * * *$ & $-0.017 * * *$ & $-0.019 * * *$ & $-0.019 * * *$ & $0.024^{* * *}$ & $0.022 * *$ & 0.010 & 0.010 \\
\hline & $(0.004)$ & $(0.004)$ & $(0.004)$ & $(0.004)$ & $(0.009)$ & $(0.009)$ & $(0.009)$ & $(0.009)$ \\
\hline \multirow[t]{2}{*}{ Married } & $-0.007 * * *$ & $-0.007 * * *$ & $-0.007 * * *$ & $-0.007 * * *$ & $-0.040 * * *$ & $-0.041 * * *$ & $-0.041 * * *$ & $-0.041 * * *$ \\
\hline & $(0.002)$ & $(0.002)$ & $(0.002)$ & $(0.002)$ & $(0.005)$ & $(0.005)$ & $(0.005)$ & $(0.005)$ \\
\hline \multirow[t]{2}{*}{ Children } & $0.008^{* * *}$ & $0.008^{* * *}$ & $0.008^{* * *}$ & $0.008^{* * *}$ & $0.014^{* * *}$ & $0.014^{* * *}$ & $0.012^{* *}$ & $0.012^{* *}$ \\
\hline & $(0.003)$ & $(0.003)$ & $(0.003)$ & $(0.003)$ & $(0.005)$ & $(0.005)$ & $(0.005)$ & $(0.005)$ \\
\hline \multirow[t]{2}{*}{ Year 2008} & $-0.003 * *$ & $-0.003^{*}$ & $-0.003^{*}$ & $-0.003^{*}$ & $-0.006^{* *}$ & $-0.006^{* *}$ & $-0.005^{*}$ & $-0.005^{*}$ \\
\hline & $(0.002)$ & $(0.002)$ & $(0.002)$ & $(0.002)$ & $(0.003)$ & $(0.003)$ & $(0.003)$ & $(0.003)$ \\
\hline \multirow[t]{2}{*}{ Log Income } & $0.014^{* * *}$ & $0.013^{* * *}$ & $0.013^{* * *}$ & $0.013^{* * *}$ & $0.041 * * *$ & $0.040^{* * *}$ & $0.036^{* * *}$ & $0.036^{* * *}$ \\
\hline & $(0.002)$ & $(0.002)$ & $(0.002)$ & $(0.002)$ & $(0.004)$ & $(0.004)$ & $(0.004)$ & $(0.004)$ \\
\hline \multirow[t]{2}{*}{ Financial Literacy } & & 0.003 & 0.003 & $0.004^{*}$ & & $0.015^{* * *}$ & $0.013^{* * *}$ & $0.010^{* *}$ \\
\hline & & $(0.002)$ & $(0.002)$ & $(0.002)$ & & $(0.004)$ & $(0.004)$ & $(0.004)$ \\
\hline Digital Skills & & & $0.008^{*}$ & $0.011^{*}$ & & & $0.049 * * *$ & $0.037 * * *$ \\
\hline
\end{tabular}




\begin{tabular}{|c|c|c|c|c|c|c|c|c|}
\hline & & & $(0.004)$ & $(0.006)$ & & & $(0.008)$ & $(0.011)$ \\
\hline $\begin{array}{l}\text { Financial Literacy } \\
* \text { Digital Skills }\end{array}$ & & & & -0.006 & & & & 0.019 \\
\hline & & & & $(0.008)$ & & & & (0.014) \\
\hline Observations & 26,032 & 26,032 & 26,032 & 26,032 & 26,032 & 26,032 & 26,032 & 26,032 \\
\hline R-squared & 0.015 & 0.016 & 0.016 & 0.016 & 0.068 & 0.069 & 0.072 & 0.073 \\
\hline
\end{tabular}

Note: Standard errors in parentheses. ${ }^{*} \mathrm{p}<0.10,{ }^{* *} \mathrm{p}<0.05,{ }^{* * *} \mathrm{p}<0.01$ 
Table 4. Multivariate Regression Model of the Probability of Being Entrepreneur by Age

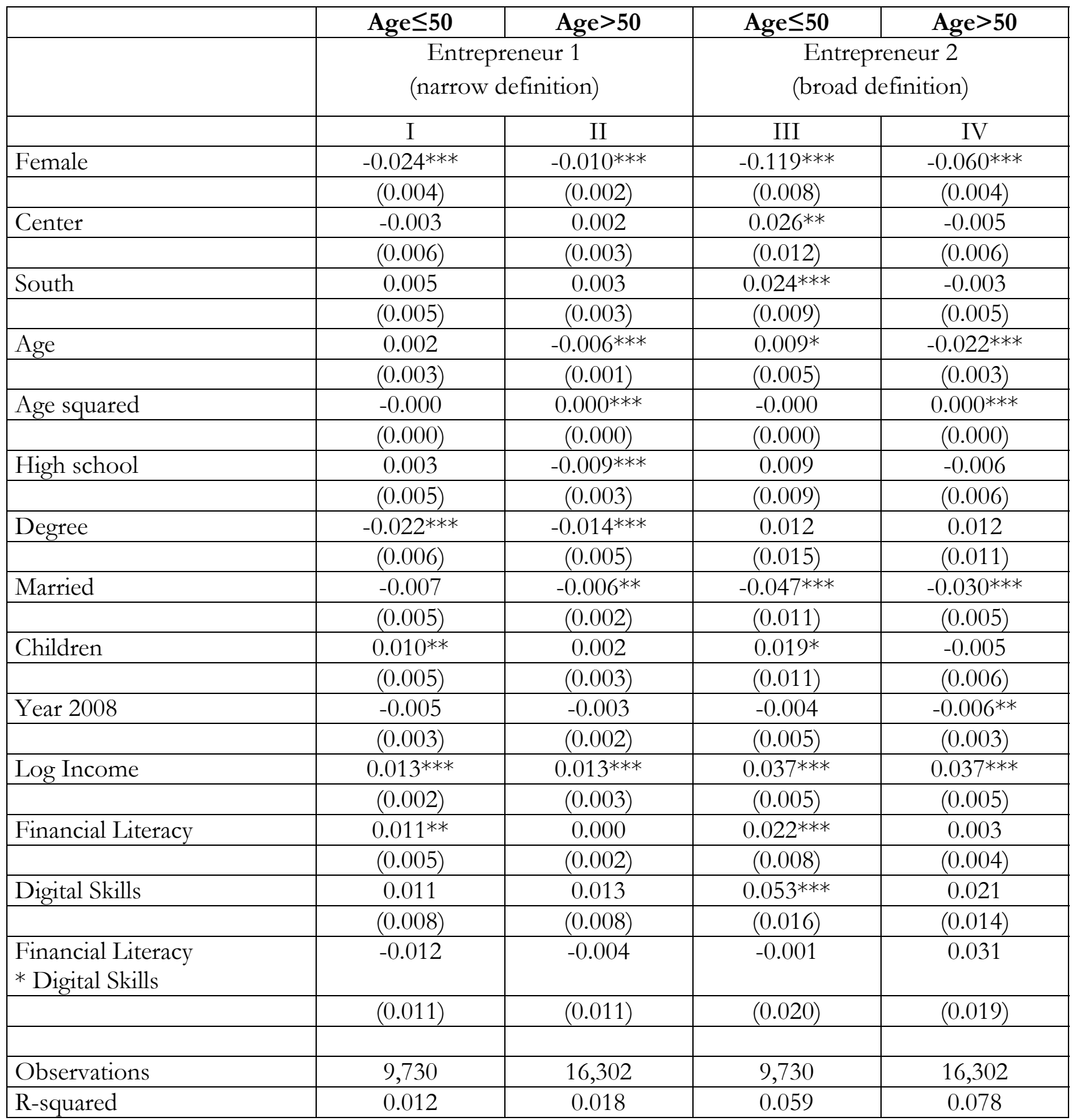

Note: Standard errors in parentheses. ${ }^{*} \mathrm{p}<0.10,{ }^{* *} \mathrm{p}<0.05,{ }^{* * *} \mathrm{p}<0.01$ 
Table 5. Multivariate Regression Model of the Probability of Being Entrepreneur by Gender for Individuals Age 50 or Below

\begin{tabular}{|c|c|c|c|c|}
\hline & Male & Female & Male & Female \\
\hline & \multicolumn{2}{|c|}{$\begin{array}{c}\text { Entrepreneur } 1 \\
\text { (narrow definition) }\end{array}$} & \multicolumn{2}{|c|}{$\begin{array}{c}\text { Entrepreneur } 2 \\
\text { (broad definition) }\end{array}$} \\
\hline & I & II & III & IV \\
\hline \multirow[t]{2}{*}{ Center } & 0.001 & -0.006 & 0.034* & 0.019 \\
\hline & $(0.009)$ & $(0.006)$ & $(0.020)$ & $(0.012)$ \\
\hline \multirow[t]{2}{*}{ South } & $0.016^{*}$ & -0.003 & $0.055 * * *$ & 0.001 \\
\hline & $(0.008)$ & $(0.005)$ & $(0.017)$ & $(0.009)$ \\
\hline \multirow[t]{2}{*}{ Age } & 0.001 & 0.003 & $0.018 * *$ & 0.005 \\
\hline & $(0.005)$ & $(0.003)$ & $(0.009)$ & $(0.005)$ \\
\hline \multirow[t]{2}{*}{ Age squared } & -0.000 & -0.000 & -0.000 & -0.000 \\
\hline & $(0.000)$ & $(0.000)$ & $(0.000)$ & $(0.000)$ \\
\hline \multirow[t]{2}{*}{ High school } & 0.007 & -0.001 & 0.016 & 0.003 \\
\hline & $(0.008)$ & $(0.005)$ & $(0.016)$ & $(0.009)$ \\
\hline \multirow[t]{2}{*}{ Degree } & $-0.031 * * *$ & $-0.018 * *$ & -0.033 & $0.042 * * *$ \\
\hline & $(0.010)$ & $(0.007)$ & $(0.024)$ & $(0.016)$ \\
\hline \multirow[t]{2}{*}{ Married } & 0.006 & $-0.015^{* *}$ & $-0.041 *$ & $-0.051 * * *$ \\
\hline & $(0.008)$ & $(0.007)$ & $(0.022)$ & $(0.012)$ \\
\hline \multirow[t]{2}{*}{ Children } & 0.008 & 0.009 & 0.022 & 0.012 \\
\hline & $(0.008)$ & $(0.006)$ & $(0.019)$ & $(0.011)$ \\
\hline \multirow[t]{2}{*}{ Year 2008} & -0.009 & -0.001 & -0.002 & -0.005 \\
\hline & $(0.006)$ & $(0.003)$ & $(0.009)$ & $(0.006)$ \\
\hline \multirow[t]{2}{*}{ Log Income } & $0.016^{* * *}$ & $0.010 * * *$ & $0.051 * * *$ & $0.025 * * *$ \\
\hline & $(0.003)$ & $(0.003)$ & $(0.007)$ & $(0.005)$ \\
\hline \multirow[t]{2}{*}{ Financial Literacy } & $0.017 * *$ & 0.007 & $0.040^{* * *}$ & 0.008 \\
\hline & $(0.008)$ & $(0.005)$ & $(0.014)$ & $(0.008)$ \\
\hline \multirow[t]{2}{*}{ Digital Skills } & 0.017 & 0.007 & $0.083 * * *$ & $0.029 *$ \\
\hline & $(0.013)$ & $(0.009)$ & $(0.026)$ & $(0.017)$ \\
\hline \multirow{2}{*}{$\begin{array}{l}\text { Financial Literacy } \\
* \text { Digital Skills } \\
\end{array}$} & -0.022 & -0.003 & -0.008 & 0.004 \\
\hline & $(0.016)$ & $(0.011)$ & $(0.033)$ & $(0.022)$ \\
\hline Observations & 4,302 & 5,428 & 4,302 & 5,428 \\
\hline R-squared & 0.013 & 0.007 & 0.039 & 0.027 \\
\hline
\end{tabular}




\section{References}

Alesina, A.F., Lotti, F., and Mistrulli, P.M. 2013. Do Women Pay More for Credit? Evidence from Italy, Journal of The European Economic Association, 11(1), 45-66.

Almenberg, J., and Dreber, A. 2015. Gender, stock market participation and financial literacy. Economic Letters, 137, 140-142.

Astebro, T., and Thompson, P. 2011. Entrepreneurs: Jacks of all trades or hobos? Research Policy, 40, 637-649.

Atalay E., Phongthiengtham P., Sotelo S., and Tannenbaum D. 2018. New Technologies and the Labor Market. Journal of Monetary Economics, 97, 48-67.

Autio, E., Nambisan, S., Thomas, L.D.W., and Wright, M. 2018. Digital affordances, spatial affordances, and the genesis of entrepreneurial ecosystems. Strategic Entrepreneurship Journal, 12, 72 95.

Autor, D. H. 2015. Why Are There Still So Many Jobs? The History and Future of Workplace Automation. Journal of Economic Perspectives, 29(3), 3-30.

Autor, D., Frank L., and Murnane, R. 2003. The Skill Content of Recent Technological Change: An Empirical Exploration. Quarterly Journal of Economics, 118(4), 1279-1333..

Bi, R., Davison, R. M., and Smyrnios K. X. 2017. E-business and fast growth SMEs. Small Business Economics, 48(3), 559-576.

Bianchi, M. 2018. Financial literacy and portfolio dynamics. The Journal of Finance, 73(2), 831-859.

Borghans, L., and ter Weel, B.. 2006. Do We Need Computer Skills to Use a Computer? Evidence from Britain. Labour, 20(3), 505-532.

Bosma, N., and Harding, R. 2006. Global entrepreneurship monitor 2006 results report. Babson Park, MA: Babson College. 
Braun, P. 2010. A skilling framework for women entrepreneurs in the knowledge economy. Contemporary Issues in Entrepreneurship Research, 1, 35-53.

Brown, M., and Graf, R.. 2013. Financial literacy and retirement planning in Switzerland. Numeracy, 6(2).

Bruhn, M., and Zia, B. 2011. Stimulating managerial capital in emerging markets: The impact of business and financial literacy for young entrepreneurs. World Bank Working Paper, 5642.

Brush, C. 1992. Research on women business owners: Past trends, a new perspective and future directions. Entrepreneurship: Theory \& Practice, 16(4), 5-31.

Bucher-Koenen, T., and Lusardi, A. 2011. Financial literacy and retirement planning in Germany. Journal of Pension Economics and Finance, 10(4), 565-84.

Bucher-Koenen, T., Lusardi, A., Alessie R., and Van Rooij, M. 2017. How financially literate are women? An overview and new insights. Journal of Consumer Affairs, 51(2), 255-283.

Chihmao, H., Parker, S.C., van Praag, C.M. 2017. Risk, balanced skills and entrepreneurship. Small Business Economics, 48, 287-302.

Consoli D., Vona F., and Rentocchini F. 2016. That Was Then, This Is Now: Skills and Routinization in the 2000s. Industrial and Corporate Change, 25(5), 847-866.

Ćumurović, A and Hyll, W. 2018. Financial literacy and self-employment. The Journal of Consumer Affairs.

Cupák, A., Fessler, P., Schneebaum, A., and Silgoner, M. 2018. Decomposing gender gaps in financial literacy: New international evidence. Economics Letters, 168, 102-106.

Dalla Pellegrina, L., Frazzoni S., Rotondi, Z., and Vezzulli, A. 2017. Does ICT adoption improve access to credit for small enterprises? Small Business Economics, 48(3), 657-679. 
Dholakia, R. R., and Kshetri N. 2004. Factors Impacting the Adoption of the Internet among SMEs. Small Business Economics, 23(4), 311-322.

Disney, R. and Gathergood, J. 2013. Financial literacy and consumer credit portfolios. Journal of Banking \& Finance, 37(7), 2246-2254.

Drexler, A., Fischer, G., and Schoar, A. 2014. Keeping it simple: Financial literacy and rules of thumb. American Economic Journal: Applied Economics, 6(2), 1-31.

Engström, P. and McKelvie, A. 2017. Financial literacy, role models, and micro-enterprise performance in the informal economy. International Small Business Journal, 35(7), 855-875.

Falck, O., Heimisch, A., and Wiederhold S. 2016. Returns to ICT Skills. OECD Education Working Papers, No. 134, OECD Publishing, Paris.

Folta, T. B., Delmar, F., and Wennberg, K. 2010. Hybrid entrepreneurship. Management Science, 56(2), 69-253.

Fonseca, R., Mullen, K.J., Zamarro, G., and Zissimopoulos, J. 2012. What explains the gender gap in financial literacy? The role of household decision making. Journal of Consumer Affairs, 46 (1), 90-106.

Grundke, R., Marcolin, L., Nguyen, T. L. B., and Squicciarini, M. 2018. Which skills for the digital era? Returns to skills analysis. OECD Science, Technology and Industry Working Papers, 2018/09, OECD Publishing, Paris.

Hafkin, N.J., and Huyer, S. 2007. Women and Gender in ICT Statistics and Indicators for Development. Information Technologies \& International Development, 4(2), 1-25.

Hilgert, M.A., Hogarth, J.M, and Beverly, S.G. 2003. Household financial management: The connection between knowledge and behavior. Federal Reserve Bulletin, 89(7), 309-22. 
Hsu, J. W. 2011. Aging and strategic learning: The impact of spousal incentives on financial literacy. Finance and Economics Discussion Series 2011-53. Board of Governors of the Federal Reserve System. Washington, DC.

Huyer, S., Hafkin, N., Ertl, H., and Dryburgh, H. 2005. Women in the information society. In From the digital divide to digital opportunities: Measuring infostates for development, edited by G. Sciadas, 135-195. Ottawa, Canada: Orbicom/ITU.

Jappelli, T., and Padula, M. 2015. Investment in financial literacy, social security, and portfolio choice. Journal of Pension Economics and Finance, 14(4), 369-411.

Klapper, L., Lusardi, A., and Panos, G. A. 2013. Financial literacy and its consequences: Evidence from Russia during the financial crisis. Journal of Banking \& Finance, 37(10), 3904-3923.

Kyndt, E., Dochy F., Michielsen M., and Moeyaert B. 2009. Employee retention: organizational and personal perspectives. Vocations and Learning, 2(3), 195-215.

Lee, S. M., Kim, J., Choi, Y., and Lee, S. 2009. Effects of IT knowledge and media selection on operational performance of small firms. Small Business Economics, 32(3), 241-257.

Lusardi, A. 2011. Americans' financial capability. National Bureau of Economic Research Working Paper 17103.

Lusardi, A., Michaud, P.C., and Mitchell, O.S. 2017. Optimal financial knowledge and wealth inequality. Journal of Political Economy, 125 (2), 431-477.

Lusardi, A., and Mitchell, O.S. 2007a. Baby boomers retirement security: The role of planning, financial literacy and housing wealth. Journal of Monetary Economics, 54, 205-224.

Lusardi, A., and Mitchell, O.S. 2007b. Financial literacy and retirement preparedness: evidence and implications for financial education. Business Economics, 42(1), 35-44. 
Lusardi, A., and Mitchell, O.S. 2008. Planning and financial literacy: How do women fare? American Economic Review, 98 (2), 413-17.

Lusardi, A., and Mitchell, O.S. 2011a. Financial literacy and planning: implications for retirement wellbeing. In Financial Literacy: Implications for Retirement Security and the Financial Marketplace, edited by Olivia S. Mitchell and Annamaria Lusardi, 17-39. Oxford and New York: Oxford University Press.

Lusardi, A., and Mitchell, O.S. 2011b. Financial literacy and retirement planning in the United States. Journal of Pension Economics and Finance, 10 (4), 509-25.

Lusardi, A. and Mitchell, O.S. 2011c. Financial literacy around the world: An overview. Journal of Pension Economics and Finance, 10(4): 497-508.

Lusardi, A., and Mitchell, O.S. 2014. The economic importance of financial literacy: Theory and evidence. Journal of Economic Literature, 52(1), 5-44.

Lusardi, A., Mitchell, O.S., and Curto, V. 2010. Financial literacy among the young. Journal of Consumer Affairs, 44(2), 358-80.

Lusardi, A., Mitchell, O.S., and Curto, V. 2014. Financial literacy and financial sophistication in the older population. Journal of Pension Economics and Finance, 13(4), 347-366.

Lusardi, A., Mitchell, O.S., and Oggero, N. 2017. Debt and Financial Vulnerability on the Verge of Retirement. NBER Working Paper No. 23664.

Lusardi, A., Mitchell, O.S., and Oggero, N. 2018. The Changing Face of Debt and Financial Fragility at Older Ages. American Economic Association Papers and Proceedings, 108, 407-411.

Lusardi, A., and Tufano, P. 2009. Debt literacy, financial experiences, and overindebtedness. NBER Working Paper No. 14808.

Mottola, G.R., 2013. In our best interest: Women, financial literacy, and credit card behavior. Numeracy, 6 (02), 4. 
Nambisan, S. 2017. Digital entrepreneurship: Toward a digital technology perspective of entrepreneurship. Entrepreneurship Theory and Practice, 41(6), 1029-1055.

Nambisan, S., Siegel, D., and Kenney, M. 2018. On open innovation, platforms, and entrepreneurship. Strategic Entrepreneurship Journal, 12(3), 354-368.

Nanda, R., and Sorensen, J. B. 2010. Workplace peers and entrepreneurship. Management Science, 56 (7), 26-1116.

Organization for Economic Co-operation and Development (OECD), (2004). The economic impact of ICT: Measuremen t, evidence, and implications. Paris: OECD Publishing

Organisation for Economic Co-operation and Development (OECD). 2005. Improving financial literacy: Analysis of issues and policies. OECD, Paris and Washington, D.C.

Organisation for Economic Co-operation and Development (OECD). 2013. Financial literacy and inclusion: Results of OECD/INFE survey across countries and by gender. OECD Publishing.

Potrich, A.C.G., Vieira, K.M., Coronel, D.A., and Bender Filho, R. 2015. Financial literacy in Southern Brazil: Modeling and invariance between genders. Journal of Behavioural Experimental Finance, 6, 112.

Rippa, P., and Secundo, G. 2018 Digital academic entrepreneurship: The potential of digital technologies on academic entrepreneurship. Technological Forecasting and Social Change.

Spitz-Oener, A. 2006. Technical Change, Job Tasks, and Rising Educational Demands: Looking Outside the Wage Structure. Journal of Labor Economics, 24 (2), 235-270.

Srinivasan, A., and Venkatraman, N. 2018. Entrepreneurship in digital platforms: A network-centric view. Strategic Entrepreneurship Journal, 12(1), 54-71.

Stango, V., and Zinman, J. 2009. Exponential growth bias and household finance. The Journal of Finance, 64(6), 2807-2849. 
Sussan, F., and Acs, Z. J. 2017. The digital entrepreneurial ecosystem. Small Business Economics, 49(1), $55-73$.

Van Alstyne, M., and Brynjolfsson, E., 2005. Global village or cyber-balkans? Modeling and measuring the integration of electronic communities. Management Science, 51 (6), 851-868.

Van Rooij, M., Lusardi, A., and Alessie, R. 2011. Financial literacy and stock market participation. Journal of Financial Economics, 101(2), 449-472.

Van Rooij, M., Lusardi, A., and Alessie, R. 2012. Financial literacy, retirement planning and household wealth. The Economic Journal, 122(560), 449-478.

Verstegen, L., Houkes, W., and Reymen, I. 2018. Configuring collective digital-technology usage in dynamic and complex design practices. Research Policy, forthcoming https://doi.org/10.1016/j.respol.2018.10.020

Yakoboski, P. J., Lusardi A., and Hasler, A. 2018. Millennial Financial Literacy and Fin-tech Use: Who Knows What in the Digital Era. TIAA Institute and the Global Financial Literacy Excellence Center. 


\section{DEPARTMENT OF ECONOMICS AND STATISTICS \\ UNIVERSITY OF TORINO}

Corso Unione Sovietica 218 bis - 10134 Torino (ITALY)

Web page: http://esomas.econ.unito.it/ 